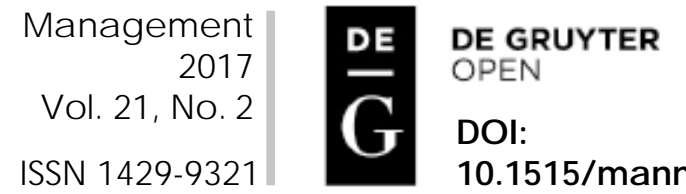

\author{
KAROLINA MAZUR \\ MONIKA INKÓW
}

\title{
Methodological aspects of innovation performance measurement in the IT sector
}

Prof. Karolina Mazur University of Zielona Góra Faculty of Economics and Management

Monika Inków, M.A. University of Zielona Góra Faculty of Economics and Management

\section{Introduction}

The IT sector is a knowledge-intensive, rapidly changing industry, in particularly facing rapid technology change. The value of the market continues to grow (http://www. bankier.pl) as does the development of the sector. The meaning of the term "innovation" has a specificity related to this particular sector and its products and technology used. The authors have formulated a research question in respect of the quality of the innovation process, however readiness for the research project proper requires resolution of an introductory methodological problem, viz. a clear definition of the indicators which will reflect the quality of such process.

The process of innovation is widely recognized and often constitutes the object of worldwide research. Unfortunately there is no homogeneous approach to the measurement of the quality of the innovation process or innovation performance, and this lack of consensus is an impediment to the process of creating competitive advantage from innovative organization. The antecedents of innovative performance of companies has 
have been studied quite extensively in the last two decades. However, the results of many studies have not yet led to a generally accepted measures of innovative performance (Hagedoorn, Cloodt 2003).

Research may be focused on systemic or management perspectives. In this paper the authors have focused on the management approach.

The research uses the method of systematic review of the literature. This paper studies the innovative performance indicators used in a sample of 125 research projects and European standards. The aim of this analysis is to attempt to classify measures of innovation performance applied in IT sector research. The results of such an analysis will be used to indicate adequate measures in the planned research project on the IT sector in the Lubuskie voivodship.

\section{Types of innovation performance}

The term innovation performance refers to the quality of the innovation process which is crucial for competing organizations. The multiplicity of approaches to this issue cannot be easily summarized and must be the object of a separate elaboration. Each approach generates a unique need for the design of an innovation performance measure. However, there are some major assumptions which have to be regarded in any research, i.e., type, sense and dimensions of innovation performance.

According to Hagedoorn and Cloodt (2003), there are two major types of innovation performance, which include:

- inventive performance as the achievements of companies in terms of ideas, sketches, models of new devices, products, processes and systems, and it is such type of performance which is frequently measured in the context of patents, where both raw counts of patents and patent citations are taken as the actual measures (p. 1366),

- technological performance, which can be defined as "the accomplishment of companies with regard to the combination of their R\&D input, as an indicator of their research capabilities, and their R\&D output in terms of patents" (p. 1367).

The authors also differentiate between innovation performance in the narrow sense (which refers to the degree to which the organization introduce inventions into the market) and in the broad sense (which refers to the implementation of such inventions in the market) (Hagedoorn, Cloodt 2003, p. 1367, Freeman, Soete, 1997).

Zheng et al. (2013, pp. 1215-1216) states that innovation performance is composed of two dimensions: innovation efficiency (the number of new products, 
the novelty of new products, the development speed of new production and the success ratio of new products in the market) and innovation profitability (the proportion of new product revenue, the improvement of quality, the reduction of cost and the advance of added value). According to Tseng \& Tseng $(2016$, p. 89) the two dimensions that define innovation performance are innovation efficacy as the degree of success an innovation enjoys and innovation efficiency as the effort put forth to accomplish the degree of success. They can be analyzed together to give an accurate measurement of innovation performance which corresponds with the OECD's Oslo Manual (OECD-EUROSTAT, 1997,p. 89). In other words, in this approach, the authors distinguish two types of innovation performance: innovation efficiency as the state of the quality of the innovation process, and innovation efficacy as the ability to produce innovation.

The authors of the present paper posit the question of just what the research customs and standards in the process of the design of indicators for the research on innovation performance are. To do so, the analysis of published research outcomes was analyzed carried out. Additionally an analysis of standards and indicators recommended formally by European authorities was conducted.

\section{The global research experience in measurement of innovation performance}

The authors conducted a systematic review of the literature based on the recommendation of W. Czakon (2011). Included in the analysis of data bases of electronic papers were those from: EBSCO, PROQUEST, ELSEVIER, Emerald, JSTOR and Wiley. Papers with the keyword "innovation performance" as research type were included. After preliminary analysis of the gathered material, the authors excluded duplicates, irrelevant papers and papers which did not include the operational description of innovation performance measurement. As a result, the authors collected a sample of 125 papers, published in the period 2001 to $2017^{1}$.

The research presented is dominated by models considering innovation performance as a dependent variable. In 37 of the research studies new products issues were used as the measure of innovation performance for the research project. The variables were (the numbers represent the appearance of such measure):

1 The list of references is very long and the authors have attached it in the cloud because presenting it in the present paper would exceed editorial recommendations. The authors have placed a full list of references for systematic review of the literature on www.karolinamazur.pl/papers. 
- proportion of new product revenue - 7,

- product novelty - 5,

- quantity of new or significantly improved products, services or processes that it has both developed and commercialized - 5,

- product competitiveness - 2,

- revenue generated from the new/innovative product - 2,

- new products index -2 ,

- modified products index -2 ,

- product innovation index - 1 ,

- speed of new product development - 2,

- rate of success of new product development -2,

- product innovation of my company outperforms competitors and we have better market responses - 1 ,

- new product development R\&D costs - 1 ,

- new product development time - 1 ,

- degree of product differentiation compared to competitors - 1 ,

- product innovation success - 1 ,

- product innovation intensity - 1,

- increase of introduction rate of new products - 1 ,

- new-to-market and new to-firm product performance -1,

- introducing innovation (process or product) - 1 .

In 35 of the research studies innovation performance was measured as a variable related to patent citations. The set of parameters contained were as follows:

- the number of patents approved - 13,

- the number of patent applications - 6,

- the number of citations of the patents possessed by the firm - 6 ,

- the value of patents - 2 ,

- number of patents in the country - 1 ,

- the number of patents per employee of local firms - 1 ,

- the number of citations that a firm's patents receive divided by the number of patents granted - 1 ,

- the number of patent applications and firm's innovativeness as a logarithm of the share of the sales of new products against total sales - 1 ,

- the number of patents granted to a firm in a given year divided by the R\&D expenditure in the period - 1 ,

- the number of patents approved compared to those of competitors - 1,

- patenting frequency - 1,

- the age of patents - 1 . 
Only 29 research studies used measures of innovation performance that referred to sales as process outcomes (and only in one case did the measure refer to profit).

The dominating way of measuring innovation performance was the number of patent applications and this needs a commentary from the side of the authors. Patents granted are assigned a higher value in performance measurement (Tseng et al. 2011). As indicated in the previous point, many studies have used the patent count analysis as a measure of innovation performance, seeing it as a more sophisticated measure of a firm's innovation (e.g., Hagedoorn \& Cloodt 2003, Hsu et al. 2015, Chen et al., 2012). Patents are the ultimate measure of the output of inventive activity. In the cases studied they were often the object of statistical measurement of the return on the innovation process. However the use of patent statistics in terms of value has some limitations. The first is the complicated way of patent valuation. Moreover, patents are subject to some limitation in representing economic value (Harhoff et al. 1999, Ming Ji\& Ping 2014 , p. 69). The number of patents can reflect innovation activity, but may also be the outcome of the appropriability strategy of the firm (Laursen \& Slater 2006, p. 134, Teece 1986). Many patents are not commercialized, since "for strategic reasons, some enterprises are unwilling to apply for a patent for certain critical innovations to prevent the premature leaking of information regarding their technology" (Jin 2015, p. 2212). Patent citations may also be a weak reflection of innovation performance because they can represent technological similarities of different firms and products, rather than organizational activities (Patel and Pavitt 1997).

\section{OECD standards, indexes and rates as measures of innovation performance}

Rates and indexes appeared as a type of measure in 30 research projects, while in 49 studies there was an application of multi-item constructs on the Likert scale, and other studies used simple variables.

According to Oslo Manual (2005), there are two groups of indicators relevant to the measurement of innovation process quality and performance: resources devoted to $R \& D$ and patent statistics. There may be used several complementary kinds of information, "although information is not always available at the [individual] firm level" (p. 22). To measure the outcomes of the innovation process, one can make use of the percentage of sales derived from new or improved products, and additional indicators can be obtained through qualitative questions (p. 20). It is also possible to use measures of the impacts 
on enterprise performance. For example, the proportion of turnover due to new or significantly improved products can be a measure of the innovation process impact on turnover. Additional qualitative surveys can also be a source of additional information (pp. 109-110). Patent data can be used as "an intermediate output indicator for innovation activity, and also provide information on the innovative capabilities of the enterprise" (p. 114). These indicators are designed to be used in comparable research, but they were wot used in the research analyzed in these papers. Instead of this some other rates and indexes were used: - product innovation index, which is a measure of innovation capability; it is based on extensive qualitative information about the extent and significance of each firm's innovative outputs generated during the 3 years prior to the survey (Xie et al. 2016, Romijn \& Albaladejo 2002),

- rate of success of new product development - a measure of success, which takes into account that new product development is a key business function and involves all functional groups; it considers not only short term factors but also the effectiveness over the medium and longer term. It measures success by considering five key factors: project efficiency, impact on customers, impact on the team, business results, preparation for the future (Xu et al. 2012, Wu et al. 2016),

- new products index - this is a measure of "the proportion of current sales from products newly introduced in the preceding 3 years by the SMEs", (Xie et al. 2016, Zeng el al. 2010, p. 192),

- modified products index - a measure of "the proportion of current sales from products modified in the preceding 3 years by the SMEs (Xie et al. 2016, Zeng et al. 2010, p. 192.),

- summary innovation index by the European Commission (2016) - which summarizes the performance based on 25 indicators, which are grouped into three main types - Enablers, a Firm's activities and Outputs - and eight innovation dimensions", (European Commission 2016, p. 6, Huňady \& Orviská 2014),

- the index of innovation growth, calculated by the European Commission (2013) - average annual growth rates as calculated over a five-year period; countries are classified following their growth performance relative to that of their performance group", (European Commission 2013, p.12, Huňady \& Orviská 2014).

Such measures can be very useful in conducting comparable research projects in the IT sector for any level of analysis, but there is a very weak application of such indexes and rates in the research projects analyzed in this paper and which 
were conducted in the IT sector. The lack of comparability may result from international diversification or location of the research. Most of the research focuses on an Asiatic sample, for whom the application of OECD standards may not be customary. The next section will present a discussion and recommendation of measures for the IT sector.

\section{Innovation performance measurement in the IT sector: the problem of product novelty}

Amongst the cited studies only seven research projects were conducted in the IT sector. The measurement of innovation performance in this sector mostly took into account patent issues, such as the number of citations of the patents possessed by the firm (Chen et al. 2012, Huang \& Chen 2010), the number of patents approved (Wang et al. 2015, Tseng et al. 2011, Chen \& Huang 2010), patent values (Tseng et al. 2011) and patents granted to a firm in a given year divided by the R\&D expenditure in the same period (Chen \& Huang 2010). In the study of Huang \& Chen (2010, pp. 422-423), innovation performance was categorized into two dimensions: innovation quantity (measured as the number of patents granted to a firm in a given year) and innovation quality (based on patent citation statistics).

The methodological problem of the application of such measures to IT companies in Poland is that they have limited activity in patenting. This may be for two reasons. The first is the limitation of Polish legal regulations, which assumes that only new hardware device products can be the object of patents. This is why many knowledge-intensive firms operating in the IT sector do not patent their new product designs, although in many cases new projects for customers (mostly institutional) include a new product design. Another reason is the strategic approach to appropriation regimes, which assumes that patenting in such a rapidly changing market can be costly and inefficient as an isolating mechanism. For this reason the recommendation for innovation performance measurement is to refer to the application of indicators based on new products.

Product novelty issues were also taken into account in the research projects: the increase in the proportion of new products as a percentage of total products (Singh et al. 2017), the improvement in technical characteristics and features of an existing product range (Singh et al. 2017), the adaptation of the basic and key technologies (Singh et al. 2017).

According to many opinions of IT sector entrepreneurs and to the suggestion of Singh et al. 2017, product novelty in the IT sector can be considered in two 
ways. The first approach is based on the improvement in utility of the product (e.g., new functionality or extended functionality - improvement in technical characteristics and features of existing product range,). The other way is based on the novelty of the technology used (adaptation of the basic and key technologies).

\section{Innovation performance measurement in the IT sector: the level of analysis}

The important point of this consideration is the notion that the IT sector (like other innovative industries) is based on high intellectual capital density. For this reason the individual or group level of analysis should be applied, too.

The measures used for innovation performance indicators were diversified as well as being difficult to compare and categorize, and this begged another question in the analysis in respect of what the level of measurement was. The majority of the studies focused on the organizational level (113 research projects), 6 projects focused on individual performance, 2 on group performance. One of the projects reflected a sectoral approach, 1, a regional approach, and 2 projects in the research represented a country perspective. Additionally, 21

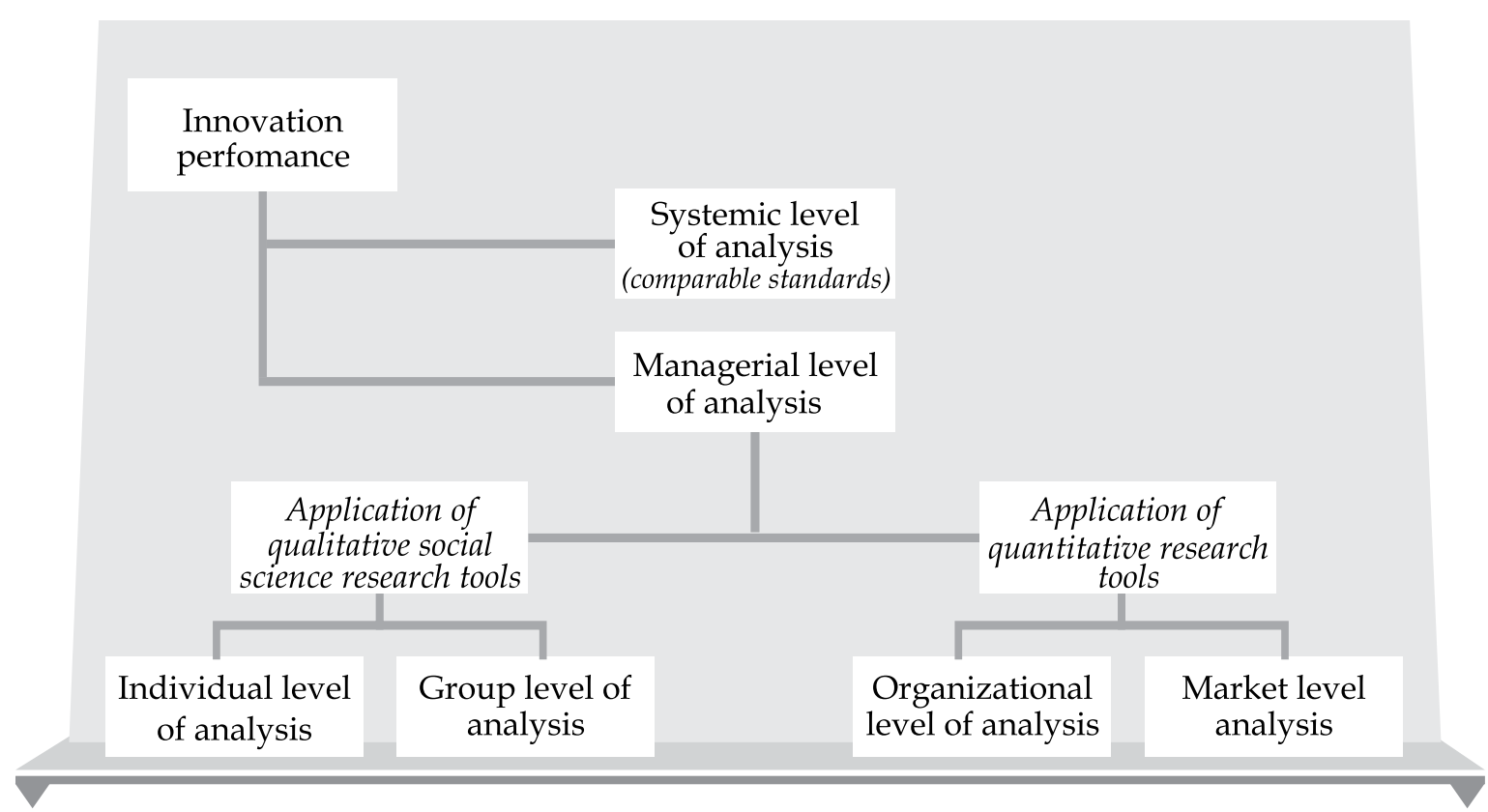

Figure 1. Levels of analysis of innovation performance

Source: own elaboration 
projects regarded market/competitive advantage problems, which refer to the organizational level but with special consideration of strategic issues.

The most often referred-to aspect in the research projects was the organizational level. The most often-used measures were new products and patents (number, value or citation), but sales from new products also appeared. The application of these measures reflects the tendency of authors to conduct quantitative research projects. This is understandable, but is also arguably a limit on the analysis of strategic issues of innovative process which refer to the personal activities of people in the workplace.

Although competitive advantage is a matter for the organization and management, innovation can be perceived as an issue at the individual and group level. Innovation can have more social connotations and has to be measured by social science research tools with the application of qualitative research methods. Hence, in the research projects there were some which made use of such research tools. For example, Chen et al. (2012, p. 161) measured innovation performance with an 8 item scale (Han et al. 2007), where one of the representative examples of an item is "I only offer my new thoughts if I want to change the current situation." Wang \& Ellinger (2011) and Wang et al. (2013) adopted Scott and Bruce's (1994) six-item innovative behavior measure. In this tool, supervisors were asked to rate their subordinates' innovative behaviors. Zhang et al. (2015) adopted the scale of Shih and Susanto's (2010) to measure the innovation performance of employees on an eight item scale, measuring three dimensions: the willingness of innovation, the behavior of innovation and the result of innovation (p. 462). Rodan \& Galunic 2004 used a scale as an assessment of individual creativity. Other authors (de la Maza-y-Aramburu et al., 2012) recognized innovation performance in terms of economic measures such as labour productivity.

To summarize this research evidence, from a management point of view, four three levels of analysis (Figure 1) can be distinguished. First - the individual level, which enables the assessment of innovation performance as a result of individual attitudes and behaviors. Second the group level of analysis, which includes the problems of social relations in the workplace, knowledge sharing, social exchange issues, etc. The analysis of innovation performance at these two levels needs to employ the qualitative research tools which are suitable for social sciences. Third - the organizational level of analysis represents the performance of the whole organization and can employ economic and other quantitative measures (number of parents, sales measures, etc.). 


\section{Conclusions}

The considerations presented above have led the authors to make the following conclusions.

The first conclusion is that innovation performance can be considered in two ways. The first as an inventive performance, which is focused on workforce creativity and knowledge sharing. In this case the research conducted should consider qualitative methods, with application of the Likert scale. The second way is technological performance, which is focused on R\&D input and outputs such as new products or patents. In this approach the quantitative methods should be applied.

Two dimensions of innovation performance should be considered: innovation efficiency and innovation efficacy.

The research projects studied considered innovation performance indicators mostly in terms of patents and new products. The measures based on patents (approval, value and citation) have many limitations in general and especially as an indicator for use in the IT sector, where patenting practices can be limited. So any measures based on patenting practices can be used only as an additional support source of information. Measures based on new products also have some limitations, because there is no clear approach to product novelty. Thus, clarification is demanded for the definition of product novelty and such information should be introductory in the design of appropriate measures.

Standard measures, such as standard rates and indexes, can be used for research in the IT sector, but such a research perspective is somewhat more managerial than systemic and such standards give only a supportive outcome.

\section{Summary}

\section{Methodological aspects of innovation performance measurement in the IT sector}

The aim of the paper is to answer the research question of what innovation performance indicators are appropriate for research on innovation process in the IT sector in the Lubuskie voivodship. The authors have used the method of systematic review of literature and have analysed 125 research papers and additional sources. The research consluions are that the indicators shoud consider such aspects as the dimmension of innovation performance, the type of product novelty and level of analysis. 
Keywords: innovation performance, research methodology, IT sector, systematic review of literature.

\section{Streszczenie}

\section{Metodologiczne aspekty pomiaru sprawności innowacyjnej w sektorze IT}

Celem pracy była odpowiedźna pytanie badawcze, które wskaźniki sprawności innowacyjnej są odpowiednie $\mathrm{w}$ odniesieniu do badań nad procesem innowacji $\mathrm{w}$ sektorze IT $\mathrm{w}$ województwie lubuskim. Autorzy wykorzystali metodę systematycznego przeglądu literatury i przeanalizowali 125 prac badawczych oraz dodatkowych źródeł. Analiza pokazała, że wskaźniki powinny uwzględniać następujące aspekty: wymiary innowacyjności, rodzaj nowości i poziom analizy.

\section{Słowa}

kluczowe: sprawność innowacyjna, metodyka badań, sektor IT, systematyczny przeglad literatury.

JEL

Classification: 031

\section{References}

1. Chen, X.-H., Zhao, K., Liu, X., Wu, D.D. ( 2012), Improving employees' job satisfaction and innovation performance using conflict management, "International Journal of Conflict Management", Vol. 23, No. 2, pp. 151172, Doi: 10.1108/10444061211218276.

2. Chen C.J., Huang Y.F. (2010), Creative workforce density, organizational slack, and innovation performance, "Journal of Business Research", Vol. 63, pp. 411-417.

3. Czakon W. (2011), Metodyka systematycznego przegladu literatury, „Przegląd Organizacji", No. 3, pp. 57 - 61.

4. de la Maza-y-Aramburu X., Vendrell-Herrero F., Wilson J.R. (2012) Where is the value of cluster associations for SMEs?, "Intangible Capital", Vol. 8, No. 2, pp. 472-496.

5. European Comission, (2016), Regional Innovation Scoreboard 2016, ec.europa.eu/DocsRoom/ documents/17824/attachments/1/ translations/en/renditions/pdf (18.09.2017 - access date).

6. European Comission (2013), Innovation Union Scoreboard 2013, http:// www.eurosfaire.prd.fr /7pc/doc/1364552692_union_scoreboard_2013_ en.pdf (18.09.2017- access date) 
7. Freeman C., Soete, L. (1997), The Economics of Industrial Innovation. Pinter, London.

8. Hagedoorn J., Cloodt M. (2003), Measuring innovative performance: Is there an advantage in using multiple indicators? "Research Policy", Vol. 32, No. 8, pp. 1365-1378.

9. Han, Y., Liao, J.Q., Long, L.R. (2007), Model of development and empirical study on employee job performance construct, "Journal of Management Sciences in China", Vol. 10, pp. 62-77.

10.Harhoff, D., F. Narin, F. M. Scherer, and K. Vopel (1999), Citation frequency and the value of patented inventions. "Review of Economics and Statistics"Vol. 81, No. 3, pp. 511-515.

11. Hsu, Ch.-W., Lien, Y-Ch., Chen, H., (2015), RED internationalization and innovation performance, "International Business Review" Vol. 24 (2015), pp. 187-195, Doi:10.1016/j.ibusrev.2014.07.007.

12. http://www.bankier.pl/wiadomosc/10-najwazniejszych-faktow-natemat-polskiego-rynku-IT-7276863.html (18.09.2017 - access date).

13. Huang, Y.-F., Chen, Ch.-J., (2010), The impact of technological diversity and organizational slack on innovation, "Technovation" Vol. 30 (2010), pp. 420-428.

14. Huňady, J., Orviská, M., (2014), The impact of research and development expenditures on innovation performance and economic growth of the countrythe empirical evidence, "Cbu International Conference on Innovation, Technology Transfer and Education", Doi:10.12955/cbup.v2.454.

15. Jin, X., Wang, J., Chen, S., Wang, T., (2015), A study of the relationship between the knowledge base and the innovation performance under the organizational slack regulating, "Management Decision" Vol. 53, No. 10, pp. 2202-2225, Doi:10.1108/MD-05-2014-0253.

16. Laursen, K., Salter, A., (2006), The Role of Openness in Explaining Innovation Performance among U.K. Manufacturing Firms, "Strategic Management Journal" Vol. 27, No. 2, pp. 131-150, Doi: 10.1002/smj.507.

17. MingJi, J., Ping, Z., (2014), Research on the Patent Innovation Performance of University-Industry Collaboration Based on Complex Network Analysis, "Journal of Business-to-Business Marketing" Vol. 21, pp. 65-83, Doi: 10.1080/1051712X.2014.903454.

18. New Product Visions, Measuring New Product Development (NPD) Success, http://newproductvisions.com /blog/?p=226 (18.08.2017 access date).

19. OECD's Oslo Manual (OECD-EUROSTAT, 1997).

20. OECD's Oslo Manual (OECD-EUROSTAT, 2005).

21. Patel P, Pavitt K.L.R. (1997). The technological competencies of the world's largest firms: complex and path dependent, but not much variety. "Research Policy" Vol. 26, pp. 141-156. 
22. Rodan, S., Galunic, Ch. (2004), More than Network Structure: How Knowledge Heterogeneity Influences Managerial Performance and Innovativeness, " Strategic Management Journal" Vol. 25, No. 6, pp. 541562, Doi: 10.1002/smj.398.

23. Romijn H., Albaladejo M., (2002), Determinants of innovation capability in small electronics and software firms in southeast England, "Research Policy", Vol. 31, pp. 1053-1057, DOI: 10.1016/S0048-7333(01)00176-7.

24. Scott, S.G. and Bruce, R.A. (1994), Determinants of innovative behavior: a path model of individual innovation in the workplace, "Academy of Management Journal", Vol. 37 No. 3, pp. 580-607.

25. Shih, H.-A., Susanto, E. (2010), Conflict management styles, emotional intelligence, and job performance in public organizations, "International Journal of Conflict Management", Vol. 21 No. 2, pp. 147-168.

26. Singh, D., Khamba, J.S., Nanda, T. (2017), Influence of technological innovation on performance of small manufacturing companies, "International Journal of Productivity and Performance Management" Vol. 66 Iss. 7, pp. 838-856, Doi:10.1108/IJPPM-02-2016-0035.

27. Teece D.J. (1986). Profiting from technological innovation: implications for integration collaboration, licensing and public policy. Research Policy Vol. 15, pp. 285-305.

28. Tseng, Ch., Tseng, Ch.-Ch. (2016), Strategy for increasing innovation at post-ipo firms, "International Journal of Entrepreneurship" Vol. 20, Iss.1, pp. 84-99.

29. Tseng, Ch.-Y., Chang Pai, D., Hung, Ch.-H. (2011), Knowledge absorptive capacity and innovation performance in KIBS, "Journal of Knowledge Management" Vol. 15, No. 6, pp. 971-983, Doi:10.1108/13673271111179316.

30. Wang, X., Ma, L., Wang, Y., (2015), The impact of TMT functional background on firm performance: Evidence from listed companies in China's IT industry, "Nankai Business Review International", Vol. 6, Iss. 3, pp. 281-311, Doi:10.1108/NBRI-11-2013-0040.

31. Wang, Y.-L., Ellinger, A.D. (2011), Organizational learning: Perception of external environment and innovation performance, "International Journal of Manpower" Vol.32, No.5/6, pp.512-536, Doi:10.1108/01437721111158189.

32. Wang, Y.-L., Ellinger, A. D., Jim Wu, Y.-Ch. (2013), Entrepreneurial opportunity recognition: an empirical study of RED personnel, "Management Decision" Vol. 51 No. 2, pp. 248-266, Doi:10.1108/00251741311301803.

33. Wu, H., Chen, J., Jiao, H. (2016), Dynamic capabilities as a mediator linking international diversification and innovation performance of firms in an emerging economy, "Journal of Business Research" Vol. 69 (2016), pp. 2678-2686.

34. Xie, X., Wu, Y., Zeng, S. (2016), A theory of multi-dimensional organizational innovation cultures and innovation performance in transitional economies: The role of team cohesion, "Chinese Management Studies" Vol. 10, Iss.: 3, pp.458-479, Doi:10.1108/CMS-01-2016-0023. 
35. Xu, G., Liu, X., Zhou, Y., Su, J. (2012), Effects of relational embeddedness on technological innovation: An empirical study in China, "Chinese Management Studies" Vol. 6, Iss. 1, pp. 108-123, Doi:10.1108/17506141211213816.

36. Zeng, S.X., Xie, X.M., Tam, C.M. (2010), Relationship between cooperation networks and innovation performance of SMEs, "Technovation" Vol. 30, pp. 181-194.

37. Zhang, S.J., Chen, Y. Q., Sun, H. (2015), Emotional intelligence, conflict management styles, and innovation performance: An empirical study of Chinese employees, "International Journal of Conflict Management" Vol. 26, Iss. 4, pp. 450-478, Doi:10.1108/IJCMA-06-2014-0039.

38. Zheng, S., Li, H., Wu. (2013), Network resources and the innovation performance: Evidence from Chinese manufacturing firms, "Management Decision" Vol. 51, Iss. 6, pp.1207-1224, Doi:10.1108/MD-02-2012-0102. 